\title{
Ukrainian scientists charged over transfer of data to West
}

London

The Ukrainian Security Service has arrested a prominent marine biologist, Sergei Piontkovski of the Institute of Biology of Southern Seas (IBSS) in Sebastopol, on charges of transferring secret information abroad and handling hard currency illegally. Four other scientists from the institute are facing arrest on the same charges.

Files and computers from the institute have been seized, and it is understood that the five scientists are being interrogated by the security service. Piontkovski, who recently returned from a period of research at Stony Brook in the United States, is due to appear in court in about a month, and could face up to 20 years in prison.

Piontkovski, an internationally known marine biologist, has received funding from international organizations and foreign governments. These include the European aid programme INTAS, the US Office of Naval Research - for a project on bioluminescence - and the British government, which paid for a plankton biodiversity project.

The British grant, funded through the Darwin Initiative, has come under particular scrutiny. The scientists are being questioned about what is being described as the "criminal transfer" of Ukrainian scientific information to the west, as well as the transfer to their institute of hard currency from Britain.

Piontkovski's work with institutions such as the Plymouth Marine Laboratory and the Royal Society in Britain, Amsterdam University in the Netherlands, and the Office of Naval Research and the Smithsonian Institution in the United States, is under scrutiny.

Robert Williams of the Plymouth Marine Laboratory, the principal scientist on the Darwin Initiative project, has expressed concern at the actions of the Ukraine authorities. He points out that all the data for the international projects was biological information collected in international waters between 1950 and 1989.

"It has no strategic importance whatsoever," says Williams. Piontkovski appears to have been collecting plankton species data, temperature, salinity and density data.

Meanwhile the Ukrainian Security Service has begun searches in another scientific organization, the Institute of Marine Geophysics (MHI), situated some 200 metres from IBSS. Last Saturday (23 October) the Sebastopol scientists launched a campaign to collect signatures to ask the Ukrainian president Leonid Kuchma to intervene. It is understood that the directors of the IBSS and the MHI are taking up the issue with the Ukrainian National Academy of Sciences.

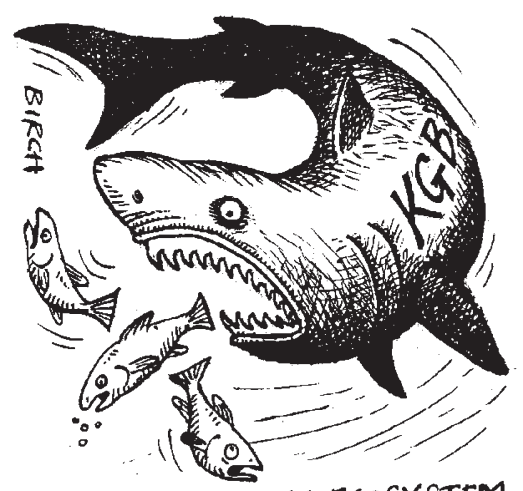

UKRAINE MARINE ECOSYSTEM

The Ukrainian embassies in Moscow and London declined to comment. But they confirm that the sentence for spying can be up to 15 years in prison. Illegal currency operations carry a five-year sentence, with confiscation of all belongings. The US embassy in Kiev was unable to confirm rumours on Tuesday that the US ambassador was to issue a statement on the situation.

"This will knock back science a decade, to pre-Soviet strictures," says Williams. "People will not be prepared to collaborate." Williams has written to NATO and to the Ukrainian academy warning that, if the situation cannot be resolved, conferences such as the European Marine Biology Symposium, scheduled for Sebastopol next autumn, could be cancelled.

Williams confirms that Piontkovski has consistently tried to direct funds to colleagues in the Ukraine looking for support and grants. He says that IBSS directors have encouraged staff — who are only being paid by the institute for two days work a week to find external sources of funding.

Piontkovski is reported to have been receiving hard currency through his role as the project director in the Ukraine for the Darwin Initiative project. He was responsible for purchasing equipment and distributing funds to IBSS colleagues. To date he has received one cash transfer from the Bank of England.

Some suggest Piontkovski was reported to the security service by a staff member. This came when moves were made to promote Piontkovski to head of department at IBSS.

The IBSS deputy director, Yury Tokarev, who is one of the researchers under investigation, has written to the chairman of the state science committee to defend himself and his colleagues. "I hope that common sense will win, and that our contacts with the foreign scientists will not be broken by the security officers," he wrote. Natasha Loder \& Carl Levitin
Indian government
faces controversy
over new IT ministry

New Delhi

India's coalition government, led by the Bharatiya Janata Party since this month's general election, has stirred controversy with plans to create a broad ministry for information technology (IT), to be headed by a non-technical person.

Because of the birth pains and confusion over its terms of reference, the ministry, whose creation was announced last week, will be under the control of the prime minister, Atal Behari Vajpayee, until a minister is appointed.

In the meantime, a senior official from the Indian Administrative Service has been appointed secretary to the ministry, causing concern in the country's IT industry.

The main obstacle to the creation of the ministry is likely to be existing ministries, whose authority and powers will be diluted as some of their responsibilities are transferred.

Government officials say that the IT ministry will promote Internet, ecommerce and knowledge-based industries without encroaching on existing ministries. But the Department of Electronics will come under the IT ministry, which will also take over the Internet and e-commerce services of the Ministry of Telecommunications.

Some of the functions of the Ministry of Information and Broadcasting — such as Internet-on-cable and cable television - will also be taken over. So will the National Informatics Centre (NIC), the country's first and largest government computer network.

N. Seshagiri, the founding director of NIC (see Nature 366, 622; 1993) says that, although he welcomes the new ministry, "it should be run, at least initiallly, by an IT professional".

N. Chandrasekaran, director of the Centre for Development of Advanced Computing in Bangalore, argues that the ministry "will facilitate India's smooth integration into the global marketplace". But Swami Manohar, a professor of computer science at the Indian Institute of Science in Bangalore, doubts that a separate IT ministry is needed.

"Given the convergence of computing, communication and broadcasting, the partitioning of the individual domains could be contentious, and the IT ministry may find itself spending most of its energy wrangling with other ministries to sort out the turf," says Manohar. K. S. Jayaraman 